\author{
L.K. Salkeyeva ${ }^{1}$, P. Vojtíšek ${ }^{2}$, Ye.V. Minayeva ${ }^{1}$, L.M. Sugralina ${ }^{1}$, \\ A.V. Omasheva ${ }^{1}$, A.A. Muratbekova ${ }^{1}$, A.K. Salkeyeva ${ }^{3}$, K.I. Sadykov ${ }^{1}$ \\ ${ }^{I}$ Ye.A. Buketov Karaganda State University, Kazakhstan; \\ ${ }^{2}$ Charles University, Prague, Czech Republic; \\ ${ }^{3}$ Karaganda State Technical University, Kazakhstan \\ (E-mail: lsalkeeva@mail.ru)
}

\title{
Investigation of interaction between tert.-butyl diamidophosphites and alkyl halides
}

\begin{abstract}
In this article the interaction of tert.-butyldiamidophosphites with various alkyl halides with a mobile halogen atom, in particular, allyl chloride, benzyl chloride and bromomalonic ester under various conditions was studied. It was established that reactions with benzyl chloride and allyl chloride proceeded according to the classical Arbuzov reaction scheme by quartering the phosphorus atom with the formation of the corresponding benzyl and allyl amidophosphonates as the main reaction products. It was stated that the reaction proceeded ambiguously with the formation of various products mixture. This is due to the structure of the intermediate «quasiphosphonium», which depends on the nature of the solvent: the ionic form predominates in polar solvents, and the pentavalent form predominates in non-polar solvents. In addition it was proved that the direction of the reaction depended on the reaction conditions, namely, the temperature and the solvent nature. It was shown that the reaction with bromomalonic ester proceeded through the initial protonation of the phosphorus atom with the formation of a quasiphosphonium compound, the decomposition of which led to the corresponding tetraethyldiamidophosphorous acid.
\end{abstract}

Keywords: ester amides of P (III) acids, Ester amides of P (III) acids, tert-butyldiamidophosphites, alkyl halides, bromomalonic ester, bromomalonic ester.

Significant advances in the practical use of phosphorus organic derivatives and the important role of phosphorus compounds in vital processes are the basis of a large and undying interest in the chemistry of these compounds. In recent years applied chemistry of organophosphorus compounds was significantly developed, a huge experimental material was accumulated, systematized and summarized in many reviews and monographs [1-4]. At the same time theoretical researches were also developed but a theoretical approach to problems of the reaction mechanism and reactivity of organophosphorus compounds, especially for derivatives of trivalent phosphorus, turned out to be more difficult, and the results were less significant compared with data for objects of classical organic chemistry.

One of the most important and interesting reactions in organophosphorus compounds chemistry was and remains the Arbuzov reaction, or the Arbuzov rearrangement, which had a great influence on the formation and development of the chemistry of organophosphorus compounds.

Ester amides of acids P(III) are of particular interest in a series of compounds of trivalent phosphorus. Due to the presence of the P-N moiety in the molecule composition they possess two nucleophilic centers, namely, a phosphorus atom and a nitrogen atom with respect to electrophilic compounds. The phosphorus atom was believed to be the nucleophilic center in the reactions of ester amides of P(III) acids with alkyl halides occurring with an increase in the valence of the phosphorus atom, and these reactions proceed according to the Arbuzov scheme through formation of the intermediate quasiphosphonium compound. In reactions with $\mathrm{H}$-acids, which occur without changing the valence of the phosphorus atom, according to the scheme of replacing the amide group of the ester amide P(III) with an acid residue, the nitrogen atom of the system plays the role of a nucleophilic center. However a sharp discussion about the mechanism of these reactions is conducted in recent years.

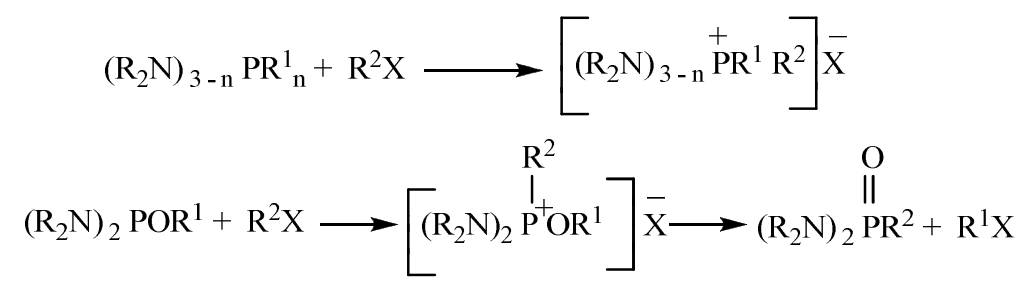




$$
\mathrm{R}_{2} \mathrm{NP}\left(\mathrm{OR}^{1}\right)_{2}+\mathrm{R}^{2} \mathrm{X} \longrightarrow\left[\mathrm{R}_{2} \mathrm{~N}-\stackrel{\stackrel{\mathrm{R}^{2}}{\mathrm{I}^{+}}\left(\mathrm{OR}^{1}\right)_{2}}{]}\right] \underset{\mathrm{X}}{\longrightarrow} \stackrel{\mathrm{R}_{2} \mathrm{O}^{\prime}}{\mathrm{R}^{\prime}} \stackrel{\mathrm{O}}{\mathrm{PR}^{2}+\mathrm{R}^{1} \mathrm{X}}
$$

From the standpoint of chemical behavior tert.-butyl esters of amidophosphorous acids have not been practically studied before. Obviously this is due to the fact that according to the literature the tert.-butyl esters of phosphorous acid are thermally unstable compounds which when heated are easily dealkylated with the release of isobutylene. Thus tri-tert.-butylphosphite $(\mathrm{t}-\mathrm{BuO})_{3} \mathrm{P}$ decomposes forming di-tert.butylphosphite $(\mathrm{t}-\mathrm{BuO})_{2} \mathrm{PHO}$ when heated above $50{ }^{\circ} \mathrm{C}$, diethyl tert.-butylphosphite $(\mathrm{EtO})_{2} \mathrm{POBu}-\mathrm{t}$ decomposes when heated above $70{ }^{\circ} \mathrm{C}$ [5]. The cause of the thermal instability of the tert.-butyl esters was not established. It was shown that the second stage of the reaction of (EtO) $)_{2} \mathrm{POBu}$-t with acrylonitrile and methyl iodide proceeded mainly with the participation of the tert.-butyl radical via the $\mathrm{S}_{\mathrm{N}} 1$ mechanism (route 1) or E2 (route 2) [6].

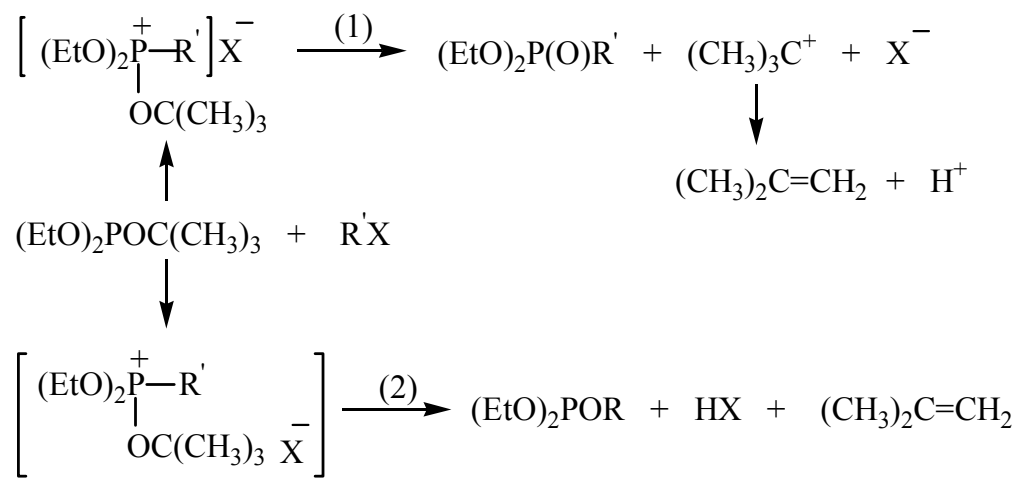

In order to study the issues of thermal stability, reactivity, and also searching for new cost-effective and experimentally convenient methods for synthesizing compounds with a $\mathrm{P}-\mathrm{C}$ bond we developed effective methods for synthesizing tert.-butyl esters of amidophosphorous acids of cyclic and acyclic structures and studied the regularities of their chemical behavior in reactions with a number of electrophilic compounds. Classical reactions synthesizing ester amides of P (III) acids using a 3-5\% excess of tertiary amine were used to obtain tert.-butyl esters. They are shown on the following schemes:

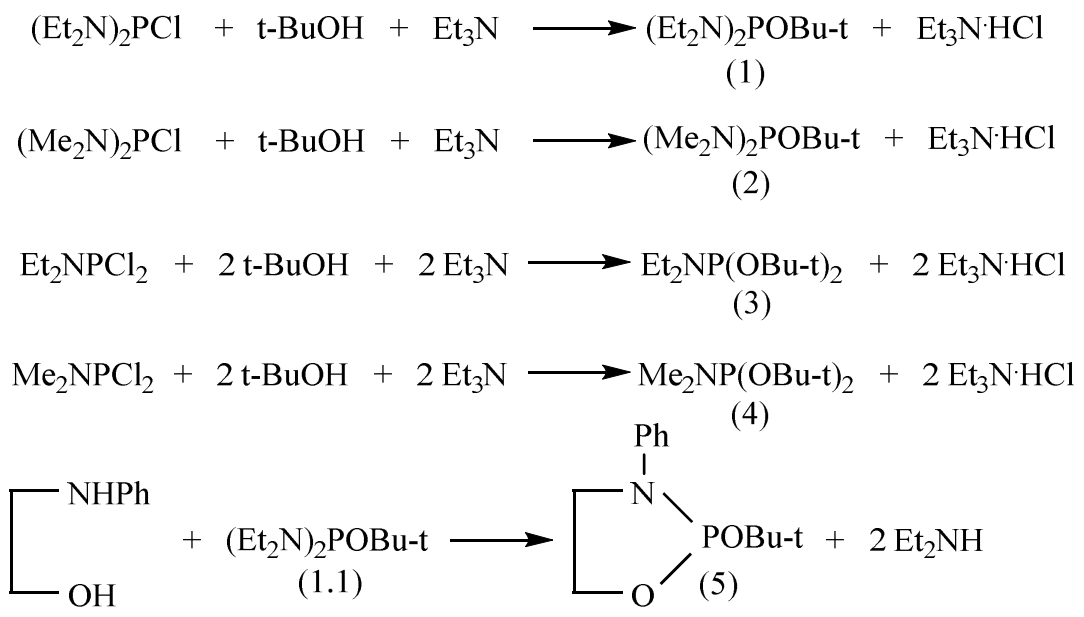

The structure of all phosphorous ester amides obtained was proved by ${ }^{31} \mathrm{P}$ NMR and ${ }^{1} \mathrm{H}$ NMR spectroscopy. As it was to be expected the signals of the phosphorus atom in the ${ }^{31} \mathrm{P}$ NMR spectra are in a weak field in the range from 110 to $130 \mathrm{ppm}$, which corresponds to the signals of the three-coordinated phosphorus atom.

In the study of tert.-butyl and di-tert.-butyl esters of amidophosphorous acids of cyclic and acyclic structures we showed that they were sufficiently thermally stable compounds. Thus according to the 
${ }^{31} \mathrm{P}$ NMR spectrum it was found that tert.-butyltetraethyldiamidophosphite (1) retained the configuration of the trivalent phosphorus atom $\left(\delta_{\mathrm{P}} 124 \mathrm{ppm}\right)$ when heated above $200{ }^{\circ} \mathrm{C}$.

In accordance with the literature data the studies related to the investigation of the chemical properties of esters with a tert.-butoxyl group are absent, apparently due to the proposed thermal instability of the above-mentioned compounds. However the presence of a tert.-butyl group in many cases can make precise the discussion points mainly related to the ambiguity of many reactions of ambident systems, in particular $\mathrm{P}(\mathrm{III})$ ester amides, and also contribute to the uniqueness of the processes, therefore, increase yield of target products.

Thus it is logical to study the Arbuzov reaction involving tert.-butyl esters of amidophosphorous acids, in particular, in reactions with various halide alkyls, both in terms of solving the controversial issues of the reaction mechanism, and in order to find effective ways to create a $\mathrm{P}-\mathrm{C}$ bond.

We showed that the reaction of phosphite (1) with ethyl bromide proceeded according to the scheme of the classical reaction with the formation of the corresponding tetraethyl diamidoethyl phosphonate (6).

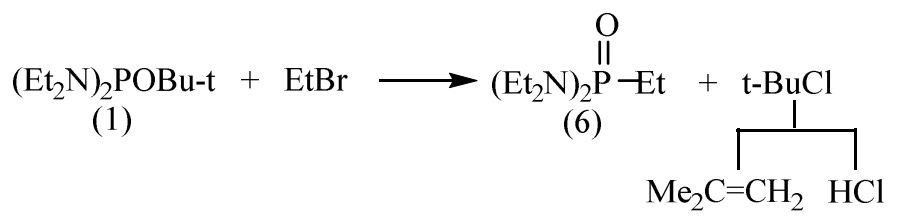

Obviously the reaction mechanism is fully consistent with the classical concepts of the two-stage process. The second stage of the reaction, apparently, proceeds according to the scheme $S_{N} 1$, as a result of which the tert.-butyl cation can be formed, which further regenerates the tert.-butyl bromide or decomposes forming isobutylene, which is fixed quantitatively by water displacement. However during the reaction partial distillation of tert.-butyl bromide was also observed.

If the reaction with ethyl bromide has no deviations from the classical concepts then the study of reactions involving reactive halogen derivatives with a mobile halogen atom encountered some difficulties associated with the ambiguity of the process. So we obtained interesting data when studying the reactions of tert.butyl esters of amidophosphorous acid with such halide alkyls as benzyl chloride, allyl chloride, which have high mobility of halogen associated with the stability of the allyl and benzyl cation and radical, and also bromomalonic ester [7,8].

When investigated the reaction of diamidophosphite (1) with benzyl chloride it was shown that the reaction proceeded rather difficult depending on the conditions and a mixture of products was formed.

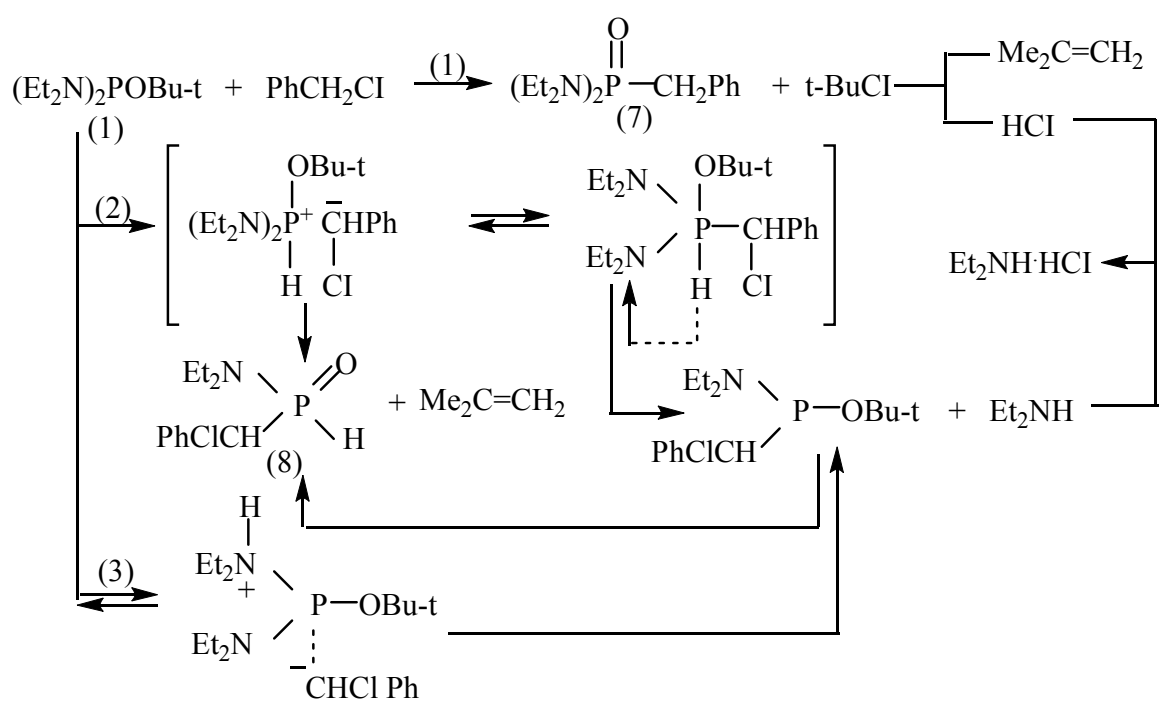

Thus, in particular, when carrying out the reaction without solvent it that the main direction of the reaction was found to be the Arbuzov rearrangement leading to the formation of tetraethyl diamidobenzylphosphonate (7), this is quite consistent with the scheme of the classical Arbuzov reaction. It is known from the literature that diamido esters of benzylphosphonic acid are patented and widely used as 
herbicides in agriculture and horticulture $[9,10]$. Our proposed method of obtaining effective herbicides favorably differs in that the direction of the reaction is well regulated when exposed to external factors (temperature, solvent), does not require the use of catalysts and solvents, sophisticated equipment and has a fairly high yield of the target product. Carrying on the reaction in solvents is significantly different from the usual scheme. It was found that when the reaction proceeded in non-polar aprotic solvents a significant amount of diethylamine hydrochloride $(50 \%)$ independent of the nature of the solvent is formed along with the benzylphosphonate. Isobutylene and diethylamido( $\alpha$-chlorobenzyl)phosphorous acid (8) with $\delta{ }^{31} \mathrm{P} 8 \mathrm{ppm}$, $\mathrm{J}_{\mathrm{PH}} 580 \mathrm{~Hz}$ were also recorded as the reaction products; the absorption band characteristic of the $\mathrm{P}-\mathrm{H}$ bond in the region of $2370 \mathrm{~cm}^{-1}$ is in the IR spectrum.

According to our ideas the reaction routes are described in the framework of a scheme involving both isomerization according to the Arbuzov reaction scheme (route 1) and the initial protonation of the phosphorus atom to form a quasiphosphonium compound (route 2), the decomposition of which, apparently, can proceed in several directions.

The structure of the intermediate «quasiphosphonium» depends on the nature of the solvent: the ionic form dominates in polar solvents, and pentacovalent one in non-polar solvents [5,6]. The formation of acid (8) can be explained within the framework of a scheme taking into account the course of the reaction both through the stage of the phosphorus atom protonation and by the nitrogen atom protonation (route 2) and the decomposition of the resulting intermediate product while maintaining the coordination of the phosphorus atom and further isomerizing the forming phosphite and isobutylene release.

The formation of a significant amount of diethylamine hydrochloride was also explained in the framework of a scheme taking into consideration the initial attack of the acidic proton of benzyl chloride on the phosphorus atom. Moreover, in our opinion, the structure of the intermediate quasiphosphonium compound can be both ionic and pentacovalent one. The decomposition of the pentavalent form of the intermediate product that prevails in the non-polar environment obviously leads to the formation of a compound while maintaining the coordination of the phosphorus atom, which subsequently seems to undergo thermal isomerization leading to an acidic phosphite (8). The ionic form of a quasiphosphonium product can directly lead to phosphite (8).

Thus for the first time in the reaction with alkyl halides containing a mobile hydrogen atom products were obtained, which formation can be explained only from the standpoint of the initial protonation of the phosphorus atom with the formation of an intermediate quasiphosphonium compound.

Carrying out the reaction of phosphite (1) with allyl chloride confirmed the previously obtained results. When carrying out the reaction under the conditions of the Arbuzov reaction, i.e. without a solvent when heated, tetraethyl diamidoallylphosphonate (9) was isolated as a reaction product which according to the literature was patented as an agricultural herbicide [10].

Similarly to the reaction with benzyl chloride the protonation reaction product (10) was isolated, in the IR spectrum of which there is a characteristic absorption band of the $\mathrm{P}-\mathrm{H}$ bond in the region of $2390 \mathrm{~cm}^{-1}$, as well as the absorption band of the $\mathrm{C}=\mathrm{C}$ bond in the region of $1625 \mathrm{~cm}^{-1}$.

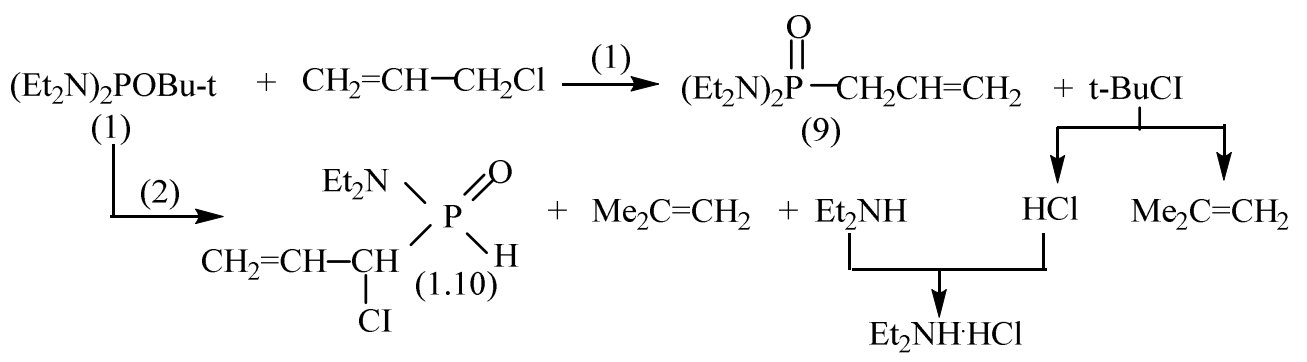

In connection with the research carried out the reaction of tert.-butyltetraethyldiamidophosphite (1) with bromomalonic ester, which also contains both a mobile halogen atom and a mobile hydrogen atom may be of undoubted interest. It was noted that when the reaction was carried out in the absence of a solvent the process proceeded very exothermically with the rapid release of isobutylene and the formation of deliquescent on air oligomer, polyaminophosphine, and ethanetetracarboxylic acid as the reaction products. This route of the reaction is fully consistent with the results of A.E. Arbuzov's work on the interaction of dialkyl esters of phosphorous acid with bromomalonic ester [11], as a result of which polyaminophosphine was also detected. 


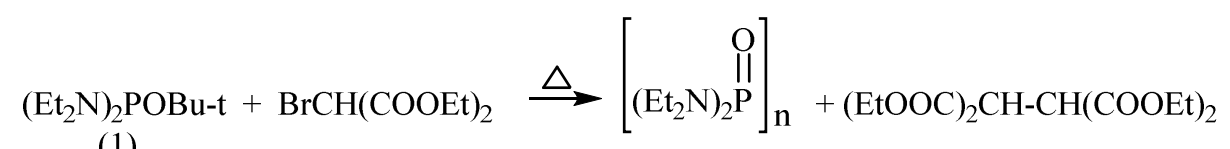

(1)

When carrying out the reaction in solvents the formation of a significant amount of diethylamine hydrochloride was also detected as the case with benzyl chloride was. In our opinion the explanation for this fact lies in the presence of both a mobile halogen atom and an acid proton which can initially attack the nucleophilic phosphorus atom.

Moreover in the presence of a solvent, the reaction proceeds according to the usual Arbuzov reaction scheme with the formation of tetraethyl diamide phosphon malonic ester (11), and by protonation of the phosphorus atom and further decomposition of the intermediate quasiphosphonium compound in various directions. In contrast to the reaction with benzyl chloride about $25-30 \%$ of the initial bromomalonic ester returns to the reaction mixture, however, the amount of isobutylene released is equimolar, this indicates another possible direction of the reaction, apparently associated with the decomposition of the quasiphosphonium compound with the formation of the corresponding phosphorus ilide, which is unstable and decomposes forming a phosphonate compound.

An interesting fact is the formation, isolation and identification of tetraethyldiamidophosphorous acid (12) as a reaction product, its structure was proved by ${ }^{31} \mathrm{P}$ NMR and IR spectroscopy. Formation of acidic phosphite (12) with $\delta^{31} \mathrm{P} 19 \mathrm{ppm}, \mathrm{J}_{\mathrm{PH}} 570 \mathrm{~Hz}$ is a direct proof of the presence of a competing protonation reaction, with the phosphorus atom being protonated more preferable than the nitrogen atom.

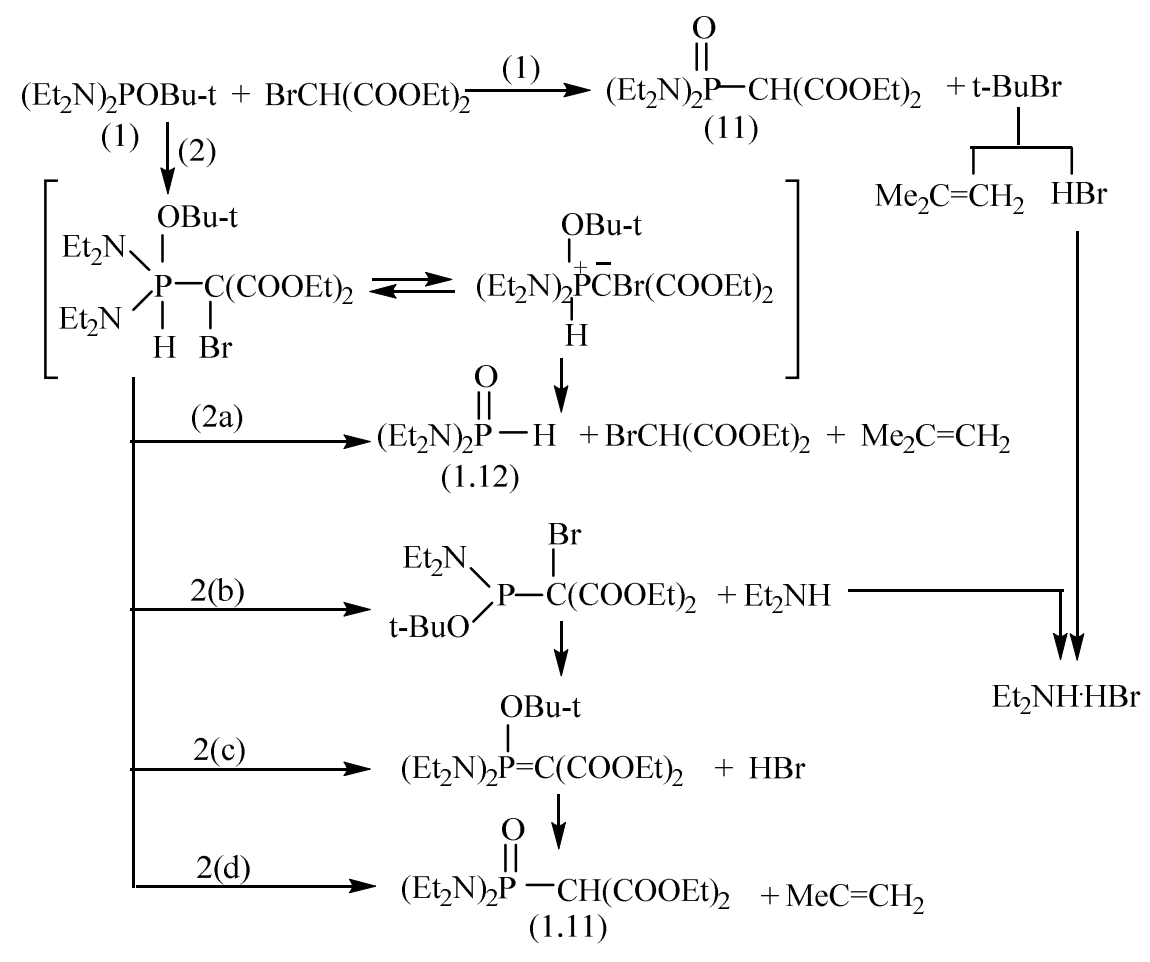

To confirm the proposed scheme we carried out the reaction in the ternary system: tert.butyltetraethyldiamidophosphite - paraform - malonic ester. Previously the possibility of condensation in the ternary system: malonic ester-aldehyde-trialkylphosphite was shown in the literature [12]. The authors found that the condensation of malonic ester with formaldehyde (paraform) and amidophosphites was complicated by the interaction of malonic ester with amidophosphites and the formation of N,N-diethylaminomalonic acid ethyl ester and the corresponding phosphite.

$$
\begin{aligned}
& \mathrm{CH}_{2}(\mathrm{COOEt})_{2}+\mathrm{Et}_{2} \mathrm{~N}-\mathrm{P} \backslash_{\mathrm{Y}}^{\prime \mathrm{X}} \longrightarrow \mathrm{CH}_{2} \underset{\mathrm{CONEt}_{2}}{-\mathrm{COOEt}}+\mathrm{EtO}^{2} \mathrm{P} \backslash_{\mathrm{Y}}>\mathrm{X} \\
& \mathrm{X}=\mathrm{Y}=\mathrm{OEt}, \mathrm{NEt}_{2}
\end{aligned}
$$


The authors of [12] isolated 2,2-carbethoxyethylphosphonic acid diethyl ester and a small amount of 2-carbethoxy-2-[carbo(N,N-diethylamido)] ethylphosphonic acid diethyl ester during condensation in the ternary system malonic ester-paraform-diethylamidodiethylphosphite. We studied the reaction in the ternary system: tert.-butyltetraethyl diamidophosphite (1) - malonic ester - paraform. It was shown that regardless of the reaction conditions there was observed the initial protonation with the formation of a quasiphosphonium compound, the decomposition of which led to the corresponding tetraethyldiamidophosphorous acid (12) fixed in the ${ }^{31} \mathrm{P}$ NMR spectrum with a chemical shift of $\delta^{31} \mathrm{P} 19 \mathrm{ppm}, \mathrm{J}_{\mathrm{PH}} 570 \mathrm{~Hz}$.

$$
\underset{(1)}{\left(\mathrm{Et}_{2} \mathrm{~N}\right)_{2} \mathrm{POBu}-\mathrm{t}}+\mathrm{CH}_{2}(\mathrm{COOEt})_{2} \underset{-\mathrm{Me}_{2} \mathrm{C}=\mathrm{CH}_{2}}{\stackrel{\left(\mathrm{CH}_{2} \mathrm{O}\right)_{\mathrm{n}}}{\longrightarrow}}\left(\underset{(12)}{\left(\mathrm{Et}_{2} \mathrm{~N}\right)_{2} \mathrm{PHO}}+\mathrm{CH}_{2}(\mathrm{COOEt})_{2}\right.
$$

Consequently the data obtained confirm our assumptions about the occurrence of competing, and, possibly, ahead of the protonation reaction of ester amide with a sufficiently strong $\mathrm{CH}$-acid, which is a malonic ester. The uniqueness of this process was demonstrated on the reaction of the starting phosphite with malonic ester, as a result of which only diamidophosphorous acid was isolated (12). So the results obtained in aggregate show that tert-butyl esters of amidophosphorous acid are very convenient «tools» in solving a number of issues especially concerning the complex reactions mechanisms, and make it possible to simulate the structure of the intermediate product using the effect of the reaction temperature, solvent, concentration of substances, etc., as well as they are convenient syntons in creating compounds with the P-C bond having wide practical application.

\section{Experimental}

Synthesis of tert.-butyl tetraethyldiamidophosphite (1)

$105.3 \mathrm{~g}(0.5 \mathrm{~mol})$ of tetraethyldiamidochlorophosphite in 2 liters of benzene was placed in a fournecked flask equipped with a mechanical stirrer, a thermometer, a reflux condenser, and a dropping funnel. At vigorous stirring a mixture of $37.0 \mathrm{~g}(0.5 \mathrm{~mol})$ of tert.-butyl alcohol and $55.6 \mathrm{~g}(0.55 \mathrm{~mol})$ of triethylamine in $200 \mathrm{ml}$ of benzene was added at $0-5{ }^{\circ} \mathrm{C}$. After stirring at room temperature for $2-3$ hours the precipitate of triethylamine hydrochloride was filtered, the solvent was removed in a water jet pump vacuum (30-40 mm Hg); $102.9 \mathrm{~g} \mathrm{(83 \% )} \mathrm{of} \mathrm{phosphite} \mathrm{(1)} \mathrm{was} \mathrm{isolated} \mathrm{by} \mathrm{distillation} \mathrm{of} \mathrm{the} \mathrm{residue;} \mathrm{bp} 52-53{ }^{\circ} \mathrm{C}$ $(0.07 \mathrm{mmHg}), d_{4}^{20} 0.8996, n_{D}^{20} 1.4510$. Found, \%: C 58.30; H 11.45; N 11.38; P 12.25. $\mathrm{C}_{12} \mathrm{H}_{29} \mathrm{~N}_{2} \mathrm{OP}$. Calculated, \%: C 58.06; H 11.69; N 11.29; P 12.59. $\delta{ }^{31} \mathrm{P} 124 \mathrm{ppm}, \delta^{1} \mathrm{H} 1.17 \mathrm{ppm}\left(\mathrm{CH}_{3}, 12 \mathrm{H}, \mathrm{t},{ }^{3} \mathrm{~J}_{\mathrm{HH}} 7 \mathrm{~Hz}\right)$, $1.43 \mathrm{ppm}\left[\left(\mathrm{CH}_{3}\right)_{3} \mathrm{C}, 9 \mathrm{H}, \mathrm{s}\right], 3.07 \mathrm{ppm}\left(\mathrm{CH}_{2}, 12 \mathrm{H}, \mathrm{m}\right)$.

Interaction of phosphite (1) with benzyl chloride

a) without solvent

$12.4 \mathrm{~g}(0.05 \mathrm{~mol})$ of phosphite (1) and $6.3 \mathrm{~g}(0.05 \mathrm{~mol})$ of benzyl chloride were mixed in an Arbuzov flask. The reaction mixture was heated on a water bath, partial distillation of $\mathrm{t}-\mathrm{BuCl}$ was observed; bp 48$50{ }^{\circ} \mathrm{C}, n_{D}^{20} 1.3860$ (reference data: bp $51-52^{\circ} \mathrm{C}, n_{D}^{20} 1.3857$ ). Tert.-BuCl mainly decomposes under distillation conditions with the release of isobutylene fixed by the method of water displacement in a gas meter $(930 \mathrm{ml}, 83 \%)$. The crystallized reaction mass in the flask was treated with water, then the free diethylamine was separated from the aqueous solution of diethylamine hydrochloride by neutralization with alkali, diethylamine has bp $54-55^{\circ} \mathrm{C}, n_{D}^{20} 1.3894$ (reference data: bp $\left.55.5^{\circ} \mathrm{C}, n_{D}^{20} 1.3873\right)$, yield was $0.4 \mathrm{~g}(11 \%)$. $4.8 \mathrm{~g} \mathrm{(34 \% )}$ of tetraethyldiamidobenzylphosphonate (7) was isolated by extraction of the aqueous portion with ether, bp 51-52 ${ }^{\circ} \mathrm{C}$ (reference data $[9,10]$ : bp 51-53 ${ }^{\circ} \mathrm{C}$ ). Found, \%: C 63.50; H 10.02; N 9.68; P 10.73. Calculated, \%: C 63.83; H 9.57; N 9.93; P 10.98. IR spectrum $\left(v, \mathrm{~cm}^{-1}\right): 1220(\mathrm{P}=\mathrm{O}), 1400-1600(\mathrm{Ph})$.

b) in a solvent (benzene)

$12.4 \mathrm{~g}(0.05 \mathrm{~mol})$ of phosphite (1) and $6.3 \mathrm{~g}(0.05 \mathrm{~mol})$ of benzyl chloride in $50 \mathrm{ml}$ of dry benzene were heated in a flask with reflux condenser. Isobutylene liberation $(950 \mathrm{ml}, 85 \%)$ was observed. Crystals of diethylamine hydrochloride of mass $2.3 \mathrm{~g}$ (yield $42 \%$ ) were separated by filtration, bp $220^{\circ} \mathrm{C}$ (reference data: bp $\left.221^{\circ} \mathrm{C}\right)$. IR spectrum of the reaction mixture $\left(\mathrm{v}, \mathrm{cm}^{-1}\right): 1220(\mathrm{P}=\mathrm{O}), 2440(\mathrm{P}-\mathrm{H})$. After distilling off the solvent the precipitated crystals of benzylphosphonate (7) were recrystallized from hexane, bp $51-52{ }^{\circ} \mathrm{C}$. The residue was distilled in vacuum, yield $2.2 \mathrm{~g} \mathrm{(18 \% )}$ of diethylamido( $\alpha$-chlorobenzyl)phosphorous acid (8), bp $147-148^{\circ} \mathrm{C}(2 \mathrm{~mm} \mathrm{Hg}), d_{4}^{20} 0.9753, n_{D}^{20} 1.4740, \delta^{31} \mathrm{P} 8 \mathrm{ppm}, \mathrm{J}_{\mathrm{PH}} 580 \mathrm{~Hz}$. 
The interaction of phosphite (1) with allyl chloride

a) without a solvent

Under reaction conditions with benzyl chloride $12.4 \mathrm{~g}(0.05 \mathrm{~mol})$ of phosphite (1) and $3.8 \mathrm{~g}(0.05 \mathrm{~mol})$ of allyl chloride formed $3.7 \mathrm{~g} \mathrm{(32 \% )} \mathrm{of} \mathrm{tetraethyldiamidoallylphosphonate} \mathrm{(9),} \mathrm{bp} 131-132{ }^{\circ} \mathrm{C}(2 \mathrm{~mm} \mathrm{Hg})$, $d_{4}^{20} 0.8293, n_{D}^{20} 1.4485$ (reference data $[9,10]$ : bp $113-114{ }^{\circ} \mathrm{C}(0.45 \mathrm{~mm} \mathrm{Hg})$.

b) in a solvent (benzene)

Under the reaction conditions with benzyl chloride $12.4 \mathrm{~g}(0.05 \mathrm{~mol})$ of phosphite (1) and $3.8 \mathrm{~g}$ $(0.05 \mathrm{~mol})$ of allyl chloride formed $2.7 \mathrm{~g}(28 \%)$ of diethylamido $(\alpha$-chloroallyl)phosphorous acid (10), bp $115-116^{\circ} \mathrm{C}(2 \mathrm{~mm} \mathrm{Hg}), d_{4}^{20} 0.8623, n_{D}^{20} 1.4335, \delta^{31} \mathrm{P} 4 \mathrm{ppm}, \mathrm{J}_{\mathrm{PH}} 560 \mathrm{~Hz}$.

The interaction of phosphite (1) with bromomalonic ester

a) without a solvent

$4.8 \mathrm{~g}(0.02 \mathrm{~mol})$ of bromomalonic ester was added dropwise to $5.0 \mathrm{~g}(0.02 \mathrm{~mol})$ of phosphite (1). Strong warming up of reaction mixture and rapid release of isobutylene $420 \mathrm{ml}(94 \%)$ were observed. The reaction mixture was a yellow crystalline mass, spreading in air, containing polyaminophosphine. White crystals of tetraethanecarboxylic acid ethyl ester $\mathrm{mp} 73-74{ }^{\circ} \mathrm{C}$ were precipitated during treatment of the reaction mixture with benzene.

b) in a solvent (benzene)

$12.0 \mathrm{~g}(0.05 \mathrm{~mol})$ of bromomalonic ester in $100 \mathrm{ml}$ of benzene was added to $12.4 \mathrm{~g}(0.05 \mathrm{~mol})$ of phosphite (1). Warming up and release of isobutylene of $1040 \mathrm{ml}(93 \%)$ were observed. The precipitate $\mathrm{Et}_{2} \mathrm{NH} \cdot \mathrm{HBr}$ was filtered, $\mathrm{mp} 210^{\circ} \mathrm{C}$. According to TLC there were two products in the benzene solution. After the solvent was distilled off by multiple distillation, $1.5 \mathrm{~g} \mathrm{(16 \% )}$ of tetraethyl diamidophosphorous acid (12) were isolated, bp $89-90^{\circ} \mathrm{C}(2 \mathrm{~mm} \mathrm{Hg}), d_{4}^{20} 0.9621, n_{D}^{20} 1.4540, \delta{ }^{31} \mathrm{P} 19 \mathrm{ppm}, \mathrm{J}_{\mathrm{PH}} 570 \mathrm{~Hz}, d_{4}^{20} 0.9600$, $\left.n_{D}^{20} 1.4545, \delta{ }^{31} \mathrm{P} 18 \mathrm{ppm}, \quad \mathrm{J}_{\mathrm{PH}} 570 \mathrm{~Hz}\right)$. IR spectrum $\left(\mathrm{v}, \mathrm{cm}^{-1}\right): 1255 \quad(\mathrm{P}=\mathrm{O}), 2370 \quad(\mathrm{P}-\mathrm{H})$. Tetraethyldiamidophosphonomalonic ester $(11)$ is a non-distilling oil, $n_{D}^{20} 1.4358$. IR spectrum $\left(\mathrm{v}, \mathrm{cm}^{-1}\right)$ : $1215(\mathrm{P}=\mathrm{O}), 1700(\mathrm{C}=\mathrm{O})$. Counter synthesis was carried out as follows. A solution of sodium malonic ester prepared from $4.0 \mathrm{~g}(0.025 \mathrm{~mol})$ of malonic ester and $0.6 \mathrm{~g}(0.025 \mathrm{~mol})$ of sodium in benzene was dropped to $5.7 \mathrm{~g}(0.025 \mathrm{~mol})$ of tetraethyldiamidochlorophosphate in benzene; NaCI was separated by filtration, benzene was distilled off. The residue was oil with $n_{D}^{20} 1.4351$.

c) reaction in the ternary system phosphite: paraform: malonic ester

A mixture of $5.0 \mathrm{~g}(0.02 \mathrm{~mol})$ of phosphite (1), $3.2 \mathrm{~g}(0.02 \mathrm{~mol})$ of malonic ester and $0.6 \mathrm{~g}(0.02 \mathrm{~mol})$ of paraform was heated in benzene for $1 \mathrm{~h}$ before the release of isobutylene in the amount of $370 \mathrm{ml}(82 \%)$ was stopped. After distilling off the solvent from the reaction mixture, $0.9 \mathrm{~g}(28 \%)$ of the malonic ester was isolated, bp $45-46^{\circ} \mathrm{C}(2 \mathrm{~mm} \mathrm{Hg}), n_{D}^{20} 1.4155$ (reference data: bp $\left.199^{\circ} \mathrm{C}, d_{4}^{20} 201.4143\right)$ and $1.2 \mathrm{~g}(32 \%)$ of tetraethyl diamidophosphite (12).

d) reaction of phosphite (1.1) with malonic ester

A mixture of $5.0 \mathrm{~g}(0.02 \mathrm{~mol})$ of phosphite (1) and $3.2 \mathrm{~g}(0.02 \mathrm{~mol})$ of malonic ester was heated in benzene for $1 \mathrm{~h}$ before stopping the release of isobutylene in an amount of $400 \mathrm{ml}(88 \%)$. After distilling off the solvent $2.6 \mathrm{~g} \mathrm{(68 \% )} \mathrm{of} \mathrm{tetraethyldiamidophosphite} \mathrm{(12)} \mathrm{was} \mathrm{isolated.}$

\section{References}

1 Пурдела Д. Химия органических соединений фосфора / Д. Пурдела, Р. Вылчану. — М.: Химия, 1972. - 752 с.

2 Kosolapoff G.M. Organic Phosphorus Compounds: in 7 Vol. - Vol. 1 / G.M. Kosolapoff, L. Maier (eds.). — New York: Wiley Interscience, $1972 .-186 \mathrm{p}$.

3 Безноско Б.К. Противовоспалительная и анальгетическая активность окисей третичных фосфинов / Б.К. Безноско, В.М. Усанова, Л.В. Журавлева, Н.А. Бондаренко, А.Н. Яркевич, А.Э. Антошин, Е.Н. Цветков // Хим.-фарм. журнал. - 1990. — № 4. - C. 22-24.

4 Тарасова Р.И. Биологически активные производные фосфорилированных карбоновых кислот / Р.И. Тарасова, В.В. Москва // Ж. общей химии. - 1997. — Т. 67, № 9. - С. 1483-1496.

5 Van Wazer M.V. Tert-butylphosphite and some of its reactions / M.V. Van Wazer // J. Org. Chem. — 1964. — Vol. 29, No. 5. - P. 1006-1008.

6 Гусев Ю.К. О реакциях некоторых смешанных эфиров фосфористой кислоты с акрилонитрилом и иодистым метилом / Ю.К. Гусев, В.Н. Чистоклетов, А.А. Петров // Ж. общей химии. - 1977. — Т. 77, № 1. — С. 45-50.

7 Газизов Т.Х. Трет-бутиловые эфиры фосфористой кислоты. Синтез и свойства / Т.Х. Газизов, Ю.В. Чугунов, А.Н. Пудовик // ДАН СССР. — 1987. — Т. 294, № 6. - С. 1382-1386. 
8 Салькеева Л.К. Трет-бутиламидофосфиты в реакции Арбузова / Л.К. Салькеева, М.Т. Нурмаганбетова, О.Ш. Курманалиев // Наука и образование - ведущий фактор стратегии Казахстана 2030: тр. Междунар. науч.-практ. конф. - Караганда: КарГТУ, 2001. — С. 334-337.

9 А.С. № 686372. СССР Способ получения тетраэтилдиамидов бензилфосфоновой кислоты / Л.И. Мизрах, Л.Ю. Полонская. Опубл. 05.03.1980.

10 Патент Японии № 48-40740 / Кувахара Масао, Рикукадо Мотоа, Оно Киити, Кавамура Юдзи, Уно Йосинори. Опубл. 03.12.1973.

11 Burgada R. Les Composes Organigues du Phosphore Trivalent. Les du la Liaison Phosphore azote / R. Burgada // Ann. Chim. - 1966. - No. 1. - P. 15-35.

12 Иванов Б.Е. Взаимодействие амидофосфитов с малоновым эфиром и параформом / Б.Е. Иванов, Л.А. Кудрявцева, С.В. Самурина, А.Б. Агеева, Т.И. Карпова // Ж. общей химии. — 1979. — Т. 49, № 8. - С. 1768-1772.

\title{
Л.К. Сәлкеева, П. Войтишек, Е.В. Минаева, Л.М. Сугралина,
} А.В. Омашева, А.А. Муратбекова, А.К. Сәлкеева, К.И. Садыков

\section{Үш-бутилдиамидфосфиттердің алкилгалогенидтерімен әрекеттесуін зерттеу}

\begin{abstract}
Мақалада үш-бутилдиамидофосфиттер галогеннің жылжымалы атомы бар әртүрлі алкилгалогенидтермен, атап айтқанда, хлорлы аллилмен, хлорлы бензилмен және броммалон эфирімен түрлі жағдайларда әрекеттесуі зерттелген. Хлорлы бензил және хлорлы аллилмен реакциялар негізгі өнімдер ретінде тиісті бензил- және аллиламидофосфонаттардың пайда болуы фосфор атомын кватернизациялау арқылы Арбузов реакциясының классикалық нұсқасына сәйкес өтетіні анықталды. Реакция әртүрлі өнімдердің қоспасын түзе жүретіні белгілі болды. Бұл еріткіш табиғатына тәуелді аралық «квазифосфония» құрылысымен байланысты: иондық пішін полярлы еріткіштерде, пентаковалентті пішін полярлы емес еріткіштерде басым. Сонымен бірге реакцияның бағыты өткізу шарттарына, атап айтқанда, температура мен еріткіштің табиғатына байланысты екендігі дәлелденді. Броммалон эфирімен реакция фосфор атомын бастапқы протондау арқылы квазифосфониялық қосылыстың түзілуімен жүретіні және оның ыдырауы сәйкес тетраэтилдиамидофосфор қышқылына әкелетіні көрсетілді.
\end{abstract}

Кілт сөздер: Р(ІІІ) қышқылдар эфироамидтері, Арбузов реакциясы, үш-бутил диамидофосфиттер, алкилгалогенидтер, броммалон эфирі, квазифосфониялық қосылыс.

Л.К. Салькеева, П. Войтишек, Е.В. Минаева, Л.М. Сугралина, А.В. Омашева, А.А. Муратбекова, А.К. Салькеева, К.И. Садыков

\section{Исследование взаимодействия трет-бутилдиамидофосфитов с алкилгалогенидами}

\begin{abstract}
В статье изучено взаимодействие трет-бутилдиамидофосфитов с разнообразными алкилгалогенидами с подвижным атомом галогена, в частности, хлористым аллилом, хлористым бензилом и броммалоновым эфиром в различных условиях. Установлено, что реакции с хлористым бензилом и хлористым аллилом протекают согласно классической схеме реакции Арбузова путем квартенизации атома фосфора с образованием в качестве основных продуктов реакции соответствующих бензил- и аллиламидофосфонатов. Установлено, что реакция протекает неоднозначно с образованием смеси различных продуктов. Это связано со структурой промежуточного «квазифосфония», которая зависит от природы растворителя: ионная форма преобладает в полярных растворителях, пентаковалентная форма - в неполярных растворителях. Кроме того, доказано, что направление реакции зависит от условий проведения, а именно от температуры и природы растворителя. Показано, что реакция с броммалоновым эфиром протекает через первоначальное протонирование атома фосфора с образованием квазифосфониевого соединения, распад которого приводит к соответствующей тетраэтилдиамидофосфористой кислоте.
\end{abstract}

Ключевые слова: эфироамиды кислот Р(ІІІ), реакция Арбузова, трет-бутилдиамидофосфиты, алкилгалогениды, броммалоновый эфир, квазифосфониевое соединение.

\section{References}

1 Purdela, D., \& Vylchanu, R. (1972). Khimiia orhanicheskikh soedinenii fosfora [Chemistry of Organic Phosphorus Compounds]. Moscow: Khimiia [in Russian]. 
2 Kosolapoff, G.M., \& Maier, L. (Eds.) (1972). Organic Phosphorus Compounds. New York: Wiley Interscience.

3 Beznosko, B.K., Usanova, V.M., Zhuravleva, L.V., Bondarenko, N.A., Yarkevich, A.N., Antoshin, A.E., \& Tsvetkov, E.N. (1990). Protivovospalitelnaia i analheticheskaia aktivnost okisei tretichnykh fosfinov [Anti-inflammatory and analgesic activity of oxides of tertiary phosphines]. Khimiko-farmatsevticheskii zhurnal - Chemical-pharmaceutical Journal, 4, 22-24 [in Russian].

4 Tarasova, R.I., \& Moskva, V.V. (1997). Biolohicheski aktivnye proizvodnye fosforilirovannykh karbonovykh kislot [Biologically active derivatives of phosphorylated carboxylic acids]. Zhurnal obshchei khimii - Russian Journal of General Chemistry, 67, 9, 1483-1496 [in Russian].

5 Van Wazer, M.V. (1964). Tret-butylphosphite and some of its reactions. J. Org. Chem., 29(5), 1006-1008.

6 Gusev, Yu.K., Chistokletov, V.N., \& Petrov, A.A. (1977). O reaktsiiakh nekotorykh smeshannykh efirov fosforistoi kisloty s akrilonitrilom i iodistym metilom [On the reactions of some mixed phosphate esters with acrylonitrile and methyl iodide]. Zhurnal obshchei khimii - Russian Journal of General Chemistry, 77, 1, 45-50 [in Russsian].

7 Gazizov, T.Kh., Chugunov, Yu.V., \& Pudovik, A.N. (1987). Tret-butilovye efiry fosforistoi kisloty. Sintez i svoistva [Phosphorous acid tert.-butyl esters. Synthesis and properties]. DAN SSSR - Reports of the Academy of Sciences of the USSR, 294, 6, 1382-1386 [in Russian].

8 Salkeeva, L.K., Nurmaganbetova, M.T., \& Kurmanaliev, O.Sh. (2001). Tret.-butilamidofosfity v reaktsii Arbuzova [Tert.butylamidophosphites in the Arbuzov reaction]. Proceedings from Science and education is a leading factor in the strategy of Kazakhstan 2030: Mezhdunarodnaia nauchno-prakticheskaia konferentsiia - International scientific and practical conference. (pp. 334-337). Karaganda: KarGTU [in Russian].

9 Mizrah, L.I., \& Polonskaya, L.Yu. (1980). Sposob polucheniia benzilfosfonovoi kisloty [The method of obtaining benzylphosphonic acid tetraethyldiamides]. Patent No. 686372. USSR. Publ. 05.03.1980 [in Russian].

10 Kuwahara Masao, Rikukado Motoa, Ono Kiiti, Kawamura Yuji, \& Uno Yosinori. (1973). Japanese Patent No. $48-40740$. Japan Publ. 03.12.1973.

11 Burgada, R. (1966). Les Composes Organigues du Phosphore Trivalent. Les du la liaison phosphore azote. Ann. Chim., 1, $15-35$.

12 Ivanov, B.E., Kudryavtseva, L.A., Samurina, S.V., Ageeva, A.B., \& Karpova, T.I. (1979). Vzaimodeistviie amidofosfitov s malonovym efirom i paraformom [Interaction of amidophosphites with malonic ester and paraform]. Zhurnal obshchei khimii Russian Journal of General Chemistry, 49, 8, 1768-1772 [in Russian]. 